\title{
EMERGING ISSUES IN EAST COAST OIL AND GAS DEVELOPMENT
}

\author{
MICHAEL HARRINGTON, Q.C.,' COLM SEVIOUR, \\ MARK MACDONALD“* and JAMES DICKSON"*
}

The authors discuss recent developments in oil and gas production in Newfoundland and Nova Scotia and the legal and regulatory regimes which affect both interest holders and oil and gas practitioners. The authors pay particular attention to jurisdictional issues arising from the intersection of federal and provincial legislation and clarify when particular legislation does or does not apply. The authors then examine the legal requirements for the approval of and implementation of oil and gas development plans, the impact of provincial royalty and tax regimes on development, and the criteria for the granting of significant discovery licenses. Finally, the authors discuss the roles of provincial and federal bodies with respect to regulatory and environmental inter-jurisdictional issues.

\section{TABLE OF CONTENTS}

I. INTRODUCTION .................... 270

II. THE OFFSHORE LEGAL AND REGULATORY REGIME $\ldots . .271$

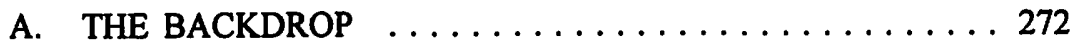

B. THE ACCORD LEGISLATION ............. 273

C. OFFSHORE APPLICATION OF CANADIAN LAWS .... 278

D. CANADIAN MARITIME LAW AND THE OFFSHORE $\ldots 280$

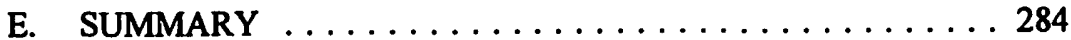

III. THE ONSHORE REGULATORY REGIME $\ldots \ldots \ldots \ldots \ldots 285$

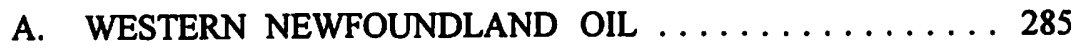

B. COAL BED METHANE IN NOVA SCOTIA . . . . . . 291

IV. FISCAL AND BENEFITS ISSUES $\ldots \ldots \ldots \ldots \ldots \ldots \ldots \ldots 29$

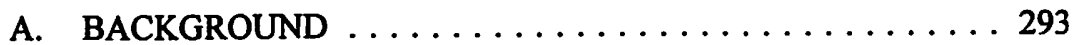

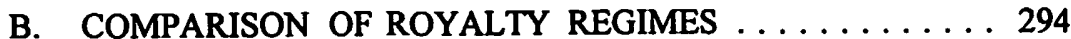

C. LOCAL BENEFITS . . . . . . . . . . . . . . . 297

D. APPLICABILITY OF PROVINCIAL TAX REGIMES .... 301

E. FUTURE DIRECTIONS ............... 301

V. SIGNIFICANT DISCOVERY LICENSES UNDER THE OFFSHORE ACCORD REGIMES $\ldots \ldots \ldots \ldots \ldots \ldots \ldots \ldots 2$

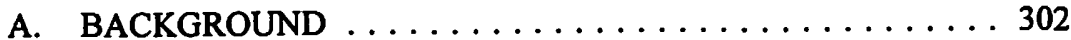

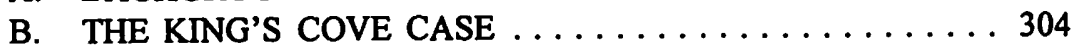

C. POSSIBLE FUTURE GUIDELINES . .......... 305

VI. REGULATORY AND ENVIRONMENTAL ISSUES

PERTAINING TO SCOTIAN SHELF GAS DEVELOPMENT . . 306

A. THE PROPOSED SABLE PROJECT $\ldots \ldots \ldots \ldots \ldots \ldots$

B. AREAS OF POTENTIAL REGULATORY

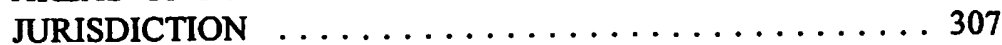

C. ENVIRONMENTAL ASSESSMENT $\ldots \ldots \ldots \ldots \ldots \ldots 310$

D. THE SABLE SOLUTION $\ldots \ldots \ldots \ldots \ldots \ldots \ldots \ldots 311$

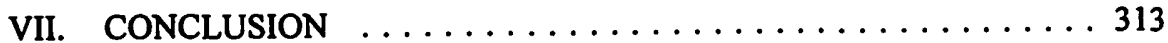




\section{INTRODUCTION}

Oil production first commenced offshore Nova Scotia in 1992 and is about to begin in Newfoundland. Other major oil and gas projects offshore Newfoundland and Nova Scotia are in the planning stages. Promising onshore exploration is ongoing in both Newfoundland (oil) and Nova Scotia (coal bed methane). It is timely to review some of the key issues arising in connection with east coast development.

The scale of proposed east coast offshore development is large. If Hibernia, Terra Nova and Sable come onstream as contemplated, east coast offshore production shortly after the year 2000 could be over 300,000 barrels of oil equivalent per day.'

As of May 30, 1996:

(1) The Hibernia Development Project ${ }^{2}$ is proceeding on schedule with platform tow out scheduled for late spring 1997 and first oil scheduled for December 1997.

(2) The Terra Nova Development Project $^{3}$ is proceeding with preparation of a development plan application and royalty negotiations with the Province of Newfoundland.

(3) The first offshore oil production in eastern Canada has taken place with the Cohasset Project. ${ }^{4}$ Production commenced in 1992 and the project has recently seen very positive results from its Balmoral well. Additional drilling is to commence in June 1996.

(4) Royalty negotiations have concluded between the Sable Offshore Energy Project ${ }^{5}$ proponents and the Province of Nova Scotia with respect to this six field natural gas project and initial regulatory filing is taking place (May 30,

I K.J. Miller, Vice-President, Frontier Development, Mobil Oil Canada (Address to Canadian Offshore Resources Exhibition (CORE) Conference, Halifax, Nova Scotia, 5 October 1995) [unpublished].

2 The participants in Hibernia are Mobil Oil Canada Properties (33.125 percent and operator), Chevron Canada Resources (26.875 percent), Petro-Canada (25 percent), Murphy Oil Company Ltd. (6.5 percent) and the Government of Canada ( 8.5 percent).

3 The participants in Terra Nova are Petro-Canada (49.2 percent and operator), Mobil Oil Canada Properties (20.7 percent), Husky Oil Operations Ltd. (15.8 percent), Murphy Oil Company Ltd. (10.7 percent) and Mosbacher Operating Ltd. (3.6 percent).

4 Effective January 1, 1996 Cohasset is held by PanCanadian Nova Scotia Limited (50 percent and operator, formerly LASMO Nova Scotia Limited) and Nova Scotia Resources (Ventures) Limited, a wholly owned subsidiary of a Nova Scotia crown corporation (50 percent).

The participants in Sable at the time of writing are Mobil Oil Canada Properties (41 percent and lead operator), Shell Canada Limited (26 percent and joint operator), Petro-Canada (18 percent), Imperial Oil ( 9 percent) and Nova Scotia Resources Limited (6 percent). 
1996). The Maritimes and Northeast Pipeline Project, ${ }^{6}$ a separate market gas pipeline project, is proposed to transport the gas to New England and, depending on demand, points in between.

Coincidental with the arrival of petroleum production offshore Newfoundland and Nova Scotia, we see the first signs of resurgence of exploration activity in a "NEP-free" environment. Areas of considerable interest for renewed exploration include the Grand Banks offshore Newfoundland where Amoco has announced its intentions to drill two exploratory wells in 1997 and has committed to a total of $\$ 90$ million in exploration work on license areas including one which is immediately adjacent to the Terra Nova oilfield.

Onshore Western Newfoundland, exploration is already underway with drilling programs currently being conducted by Hunt Oil Company (including the spudding of an offshore well) and a drilling program by Talisman Energy with a farm-in by Canadian Occidental Petroleum Ltd.

In December 1995, following the call for bids, an exploration license with a work expenditure commitment of approximately $\$ 86.4$ million was issued to Mobil (45.50 percent), Shell (45.50 percent) and Imperial Oil Resources ( 9.0 percent) in respect of a 74,206 hectare parcel adjacent to the Sable Offshore Energy Project lands.

Onshore Nova Scotia, REI Inc. of Salt Lake City, Utah is currently pursuing an exploration program for coal bed methane in the Cumberland Basin coal fields of Nova Scotia and is working on a production program for coal bed methane in the well known Stellarton Basin coal fields of Nova Scotia.

At the same time, the federal and provincial governments have established a review panel to examine the environmental and socio-economic implications of oil and natural gas exploration on George's Bank which continues to be subject to a ten-year moratorium imposed in 1990.

This article will discuss the legal regime applicable to east coast development, recent legal developments and anticipated future developments as Nova Scotia and Newfoundland make significant steps in their evolution from frontier lands to producing provinces.

\section{THE OFFSHORE LEGAL AND REGULATORY REGIME}

Any discussion of current issues pertaining to east coast development requires an understanding of the basic legal and regulatory regime. For east coast interest holders, and oil and gas practitioners, the legal and regulatory regimes manifest some unique characteristics and pose special challenges.

6 The participants are Westcoast Energy Inc. (32.5 percent), Pan Energy Corporation (32.5 percent), Mobil Oil Canada Properties (25 percent) and Eastern Enterprises Limited (10 percent), as of January 30, 1996. 
Federal legislation, provincial legislation, "mirror legislation" common law and maritime law, all come together to present an interesting but at times confusing mix.

\section{A. THE BACKDROP}

The key stepping stones leading to the present regulatory regime are a combination of international law, judicial decisions, legislation and political action including:

(1) evolving recognition under international law of the right of coastal states to explore and exploit mineral and other natural resources on their continental shelves; ${ }^{7}$

(2) the decision of the Supreme Court of Canada in the Hibernia Reference ${ }^{8}$ in 1984 recognizing the exclusive right of the federal government to explore and exploit mineral and non-renewable resources on the continental shelf and the legislative jurisdiction of the Government of Canada to make laws in relation to such minerals and natural resources;

(3) the subsequent inter-governmental agreements between Canada and Newfoundland, and Canada and Nova Scotia agreeing to a regime of joint federal-provincial management of offshore petroleum resources and ultimately leading to the passage of mirror federal and provincial legislation regulating offshore development adjacent to both provinces;

(4) the evolution of Canadian maritime law and its application to certain assets and activities in the offshore;

(5) in the case of Newfoundland, the passage of specific legislation applicable to the Hibernia project and the legal regimes applicable to that project;

(6) the passage of federal legislation applying federal and provincial laws to the offshore;

(7) the ongoing presence of the National Energy Board and its evolving jurisdiction in respect of construction and operation of pipelines and oil and gas movement; and

(8) the extension of application of other Canadian legislation to the offshore areas. 499 U.N.T.S. 311, art. 2; United Nations Convention on the Law of the Sea, 10 December 1982, UN Doc. A/Conf. 62/122, art. 77.

$8 \quad$ Reference Re Seabed and Subsoil of Continental Shelf Offshore Newfoundland, [1984] I S.C.R. 86 [hereinafter Hibernia Reference]. 


\section{B. THE ACCORD LEGISLATION}

Shortly after the Supreme Court's decision in the Hibernia Reference, and after a change in federal government in Canada, the governments of Canada and Newfoundland entered into the Atlantic Accord ${ }^{9}$ which provided for joint federal and provincial management of offshore Newfoundland petroleum resources. A Nova Scotia Accord ${ }^{10}$ followed shortly thereafter.

Pursuant to those agreements, legislated regulatory regimes were established applicable to the "offshore area" of each province through a unique model of mirror federal and provincial legislation."

For purposes of this discussion, the four pieces of mirror legislation will be collectively referred to as the Accord Acts. The federal and provincial accord legislation applicable to Newfoundland will be referred to as the Newfoundland Accord Acts. The federal and provincial legislation applicable to Nova Scotia will be referred to as the Nova Scotia Accord Acts.

The Accord Acts establish a regulatory and rights management scheme based in part upon the provisions of the Canadian Petroleum Resources Act. ${ }^{12}$ The intention of the legislation is to create a comprehensive management regime for offshore petroleum, although as will be seen particularly in the context of the Sable Offshore Energy Project, there is much room left for other regulators.

The key features of the regimes established under the Accord Acts include:

(1) Definition of an "offshore area" to which each of the Newfoundland Accord Acts and Nova Scotia Accord Acts apply. In the case of Newfoundland, the offshore area is to extend seaward from the coastline to the edge of the continental shelf or 200 miles, whichever is greater, or to a line defined by regulation. No such regulation has been passed and thus the precise limits of

Memorandum of Agreement between the Government of Canada and the Government of the Province of Newfoundland on Offshore Petroleum Resource Management and Revenue Sharing, 11 February 1985 [hereinafter Allantic Accord].

11 The Newfoundland provincial legislation is the Canada-Newfoundland Atlantic Accord Implementation (Newfoundland) Act, S.N. 1986, c. 37; the federal legislation applicable to Newfoundland is the Canada-Newfoundland Atlantic Accord Implementation Act, S.C. 1987, c. 3 [hereinafter Newfoundland Accord Acts]. The Nova Scotia provincial legislation is the CanadaNova Scotia Offshore Petroleum Resources Accord Implementation (Nova Scotia) Act, S.N.S. 1987, c. 3; the federal legislation applicable to Nova Scotia is the Canada-Nova Scotia Offshore Petroleum Resources Accord Implementation Act, S.C. 1988, c. 28 [hereinafter Nova Scotia Accord $A c t s]$. Unless otherwise noted, references to section numbers of the Accord Acts throughout this article are to sections of the federal Accord Acts for Nova Scotia and Newfoundland respectively. 
the Newfoundland offshore area is somewhat uncertain. ${ }^{13}$ In the case of Nova Scotia, the offshore area is specifically designated in Schedule I of the statute, subject to change by regulation. ${ }^{14}$

(2) Establishment of an offshore petroleum board applicable to each of offshore Newfoundland (the Canada-Newfoundland Offshore Petroleum Board or "CNOPB") and offshore Nova Scotia (the Canada-Nova Scotia Offshore Petroleum Board or "CNSOPB"). These boards are responsible for regulation of offshore petroleum activities and resources in each of the respective offshore areas. ${ }^{15}$ Specific areas of jurisdiction of the board include safety, environmental protection, administration of benefits policies, resource management rights, issuance and development approval.

(3) Establishment of a category of decisions known as "fundamental decisions" which require, subject to certain overrides and vetoes, the consent of both of the federal and provincial ministers responsible for energy matters. ${ }^{16}$ Fundamental decisions under the Accord Acts include the issuance of production licenses (leases).

(4) Provision for public review in relation to proposed development (CNOPB) or in relation to the exercise of any of its powers (CNSOPB) including the conduct of public hearings where appropriate. ${ }^{17}$

(5) Mandatory filing of benefits plans by project proponents outlining proposed adherence to local benefits principles contained in the Accord Acts. ${ }^{18}$

(6) Establishment of an interest regime ${ }^{19}$ providing for the issuance of three categories of licenses:

(a) exploration licenses, the issuance of which follow a call for bids on crown reserved lands and confer the right to explore for petroleum and the exclusive right to develop and obtain a production license;

(b) significant discovery licenses, which follow on the issuance of a declaration of the significant discovery area and which are considered in detail in Part V of this article; and

(c) production licenses (leases) which follow the declaration of a commercial discovery area.

Newfoundland Accord Acts, supra note 11, ss. 2, 5.

Nova Scotia Accord Acts, supra note 11, ss. 2, 5.

Newfoundland Accord Acts, supra note 11, ss. 9-29; Nova Scotia Accord Acts, ibid., ss. 9-30.

Newfoundland Accord Acts, ibid., ss. 30-40; Nova Scotia Accord Acts, ibid., ss. 31-38.

Newfoundland Accord Acts, ibid., s. 44; Nova Scotia Accord Acts, ibid., s. 44.

Newfoundland Accord Acts, ibid., s. 45; Nova Scotia Accord Acts. ibid., s. 45.

Newfoundland Accord Acts, ibid., ss. 57-87; Nova Scotia Accord Acts, ibid., ss. 49-90. 
(7) Collection of royalty revenues from offshore projects. Reservation of royalties to the Government of Canada. ${ }^{20}$ The reservation applies only if the petroleum is not subject to a royalty under applicable provincial legislation.

(8) Creation of a system of registration of offshore interests and instruments, the conveyance or securing of such interests, and the determination of priorities. ${ }^{21}$

(9) Establishment of mandatory annual operating licenses for parties engaged in exploration, drilling, production, processing or transportation of petroleum and mandatory authorization from the board for each such work or activity. ${ }^{22} \mathrm{~A}$ precondition of such authorization is approval of a development plan in prescribed form by the board and the filing of declarations by the applicant in prescribed form as to fitness of equipment and installations and other matters.

(10) In the Nova Scotia Accord Acts, establishment of a moratorium extending to January 1,2000 in connection with the exploration or drilling for or production, conservation, processing or transportation of petroleum in the George's Bank sector of the Nova Scotia offshore. ${ }^{23}$

(11) Establishment of an Oil and Gas Committee for each board to deal with a variety of specific issues assigned to the committee. ${ }^{24}$ Duties of the Committee will include review of board decisions on rights issuance and pooling and unitization issues.

(12) Broad regulation-making powers in respect of virtually all aspects of offshore operation. $^{25}$

(13) Authorization of board officers to grant exemptions from regulatory requirements or to recognize substituted regulatory requirements. ${ }^{26}$

Newfoundland Accord Acts, ibid., ss. 97-100; Nova Scotia Accord Acts, ibid., ss. 99-102. Newfoundland Accord Acts, ibid., ss. 102-118; Nova Scotia Accord Acts, ibid., ss. 105-21. Newfoundland Accord Acts, ibid., ss. 137-39; Nova Scotia Accord Acts, ibid., ss. 140, 142, 143. Nova Scotia Accord Acts, ibid., s. 141. The panel members are Mr. John Mullally (Chair), Ms. Susan Holtz and Mr. Ronald Loucks.

Newfoundland Accord Acts, supra note 11, ss. 141-48; Nova Scotia Accord Acts, ibid., ss. 145-52. See e.g. Newfoundland Accord Acts, ibid., s. 149 and Nova Scotia Accord Acts, ibid., s. 153. The practice under the Accord Acts has been for federal and provincial governments to also pass mirror sets of regulations. Passage of regulations has been somewhat irregular. As of May 15, 1996, federal and provincial regulations were in force for Newfoundland and Nova Scotia with respect to spills and debris liability, petroleum diving and petroleum drilling. In addition, under one or more of the Accord Acts, regulations were also in force in respect of oil and gas operations, petroleum geophysical operations, petroleum production and conservation, registration, certificates of fitness, petroleum installations and various other matters. Readers are cautioned to confirm the current status of regulations.

Newfoundland Accord Acts, ibid., s. 151; Nova Scotia Accord Acts, ibid., s. 155. 
(14) Definition of "marine installation or structure" and applying provincial "social legislation" to marine installations or structures in the offshore area ${ }^{27}$ in connection with the "exploration or drilling for or the production, conservation or processing of petroleum" within the offshore area. The social legislation includes provincial worker's compensation, labour standards and occupational health and safety legislation. Provincial trade union legislation will apply with the satisfaction of the additional requirement that the marine installation or structure be within the offshore area for the purpose of "becoming, or that is, permanently attached to, permanently anchored to or permanently resting on" the seabed or subsoil. ${ }^{28}$

(15) Spill and debris liability provisions providing for absolute liability on the part of the authorization holder up to a prescribed limitation ${ }^{29}$ for loss or damage resulting from offshore operations together with mandatory requirements in respect of proof of financial responsibility. ${ }^{30}$

(16) Detailed provisions in respect of production arrangements, including provisions for application for pooling orders and unitization orders, both of which are dealt with by the Oil and Gas Committees of the boards, and provisions for references and appeals to provincial superior courts. ${ }^{31}$

(17) Specific provisions broadly defining the commission of "waste" and establishing broad remedial orders and possible prosecution. ${ }^{32}$

Newfoundland Accord Acts, ibid., s. 152; Nova Scotia Accord Acts, ibid., s. 157. The validity of this inter-governmental delegation was upheld in the decision of the Canada Labour Relations Board in Seafarers' International Union of Canada v. Rowan Canada Limited (1992), 92 C.L.L.C. 16066; judicial review denied by Federal Court of Appeal (1993), 93 C.L.L.C. 14057 where Nova Scotia labour legislation was held applicable to the jackup rig used for drilling and production on the Cohasset Project. Newfoundland Accord Acts, ibid., s. 152(4)(b); Nova Scotia Accord Acts, ibid., s. 157(4)(b). Newfoundland Accord Acts, ibid., ss. 160-165; Nova Scotia Accord Acts, ibid., ss. 165-170. This limit was recently established by federal and provincial regulations applicable to the Newfoundland and Nova Scotia offshore areas to be in the amount of $\$ 30$ million. With regard to potential liabilities arising from a well blow-out or other similar catastrophe, the Newfoundland and Nova Scotia boards require proof of financial responsibility up to $\$ 350$ million. Proof of financial responsibility may be provided by way of well control insurance with a combined pollution and seepage endorsement with limits of $\$ 350$ million or more, or a lesser amount of insurance combined with proof of financial responsibility as reflected by audited financial statements of the operator. Associated company guarantees have also been indicated to be acceptable in circumstances where the operator is a subsidiary of a more substantial parent corporation.

Part XV of the Canada Shipping Act, R.S.C. 1985 (3d Supp.), c. 6 deals with pollution prevention and response, primarily in relation to ship source oil pollution. Section $655(2)$ excludes application of the Part to ships "on location and engaged in exploration or drilling for or production, conservation or processing of oil or gas in an area described in paragraph 3(a) or (b) of the Oil and Gas Production and Conservation Act insofar as the discharge emanates from those activities." The aforementioned areas include the offshore areas, under the Accord Acts although the Oil and Gas Production and Conservation $A c t$ is otherwise not applicable to the offshore areas.

31 Newfoundland Accord Acts, supra note 11, ss. 166-183; Nova Scotia Accord Acts, supra note 11, ss. $171-188$.

32 Newfoundland Accord Acts, ibid., ss. 154-59; Nova Scotia Accord Acts, ibid., ss. 159-64. 
(18) Extensive prosecution and enforcement provisions including provisions for issuance of orders by the board's officers and prosecution provisions with penalties including imposition of fines up to $\$ 1$ million and jail terms. ${ }^{33}$

(19) Revenue-sharing provisions applicable to the federal and provincial governments including the application of provincial consumption taxes to the offshore areas and entry into tax administration agreements between the governments. ${ }^{34}$

(20) Provision for "Fiscal Equalization Offset Payments" providing for phased reduction in equalization payments from the federal government to the provinces as royalty revenue is received from offshore projects. ${ }^{35}$

(21) Creation of offshore development funds applicable to each province. ${ }^{36}$

Because east coast development remains at an early stage, and most of the exploration activity preceded the 1986-87 period when the Accord Acts were passed, there has been only very limited judicial consideration of any of the provisions of the Accord Acts.

It is interesting to note that there remains a jurisdictional issue to be resolved between Newfoundland and Nova Scotia respecting potentially significant exploration areas south of the French islands of St. Pierre et Miquelon off the south coast of Newfoundland, in respect of which exploration agreements had previously been issued by $\mathrm{COGLA}^{37}$ under the former regulatory regime which have been extended under the Accord Acts regime. Pending further discussions between the provinces and regulators, the rights management regime in this area remains unclear. Inter-jurisdictional issues may also arise with France by virtue of the St. Pierre et Miquelon corridor which extends in a southerly direction through the continental shelf in this area.

There are many other aspects of the Accord Acts regime that are beyond the scope of this article. Another interesting jurisdictional overlap, in this case between federal and provincial governments, arises in Newfoundland. The Newfoundland Court of Appeal in the continental shelf reference litigation ${ }^{38}$ held that Newfoundland had exclusive legislative jurisdiction over the territorial sea from the low water mark seaward for three nautical miles. The Newfoundland Accord Acts define the Newfoundland offshore area effectively as beginning at the low water mark and extending seaward to the extremity of the continental shelf. This point becomes

Newfoundland Accord Acts, ibid., ss. 188-203; Nova Scotia Accord Acts, ibid., ss. 193-208.

Newfoundland Accord Acts, ibid., ss. 206-17; Nova Scotia Accord Acts, ibid., ss. 211-22.

Newfoundland Accord Acts, ibid., ss. 218-27; Nova Scotia Accord Acts, ibid., ss. 223-32.

Newfoundland Accord Acts, ibid., ss. 228-33; Nova Scotia Accord Acts, ibid., ss. 233-38.

Canada Oil and Gas Lands Administration appointed pursuant to the Canada Oil and Gas Act, S.C. 1980-81-82-83, c. 81, as rep. by Canada Petroleum Resources Act, R.S.C. 1985 (2d Supp.), c. 36, s. 130 .

Reference Re Mineral and Other Natural Resources of the Continental Shelf (1983), 145 D.L.R.

(3d) 9 (Nfld. C.A.). 
important later in this article in the context of the applicable regime for exploration activity now being conducted both onshore and offshore in western Newfoundland.

\section{OFFSHORE APPLICATION OF CANADIAN LAWS}

In addition to specific provisions of the Accord Acts, practitioners must take note of other legislation applying federal and provincial laws to the offshore areas. In the absence of express provision, federal laws are generally considered to apply only on land and within the Canadian territorial sea. ${ }^{39}$

\section{Canadian Laws Offshore Application Act}

Parliament has enacted the Canadian Laws Offshore Application $A t^{40}$ which was intended to provide a vehicle for the generalized application of federal and provincial laws to the offshore. It is noteworthy, however, that the legislation extends such extraterritorial application only to certain specific areas:

(1) on or under any "marine installation or structure" from the time it is attached or anchored to the continental shelf in connection with the exploration of that shelf or the exploitation of its mineral or other non-living resources until the marine installation or structure is removed from the waters above the continental shelf; ${ }^{41}$

(2) on or under any artificial island constructed, erected or placed on the continental shelf; and

(3) in such safety zone surrounding the marine installation or structure or artificial island referred to in (1) or (2) as is determined by or pursuant to regulation.

The Governor in Council may, by regulation, make federal laws or provisions thereof generally applicable in stated circumstances in or above the continental shelf or the exclusive economic zone. ${ }^{42}$

The legislation also provides that federal laws shall be applied as if the places covered by the legislation formed part of the territory of Canada. ${ }^{43}$

As defined in the Territorial Sea and Fishing Zones Act, R.S.C. 1985, c. T-8. The territorial sea defines the outer limit of the territory of Canada and is the so-called twelve mile limit, the twelve miles being measured from a series of baselines defined in the $\mathrm{Act}$.

S.C. 1990, c. 44. Note that Bill C-26, Oceans Act, Canada 1996, will, if passed, repeal and replace, in essentially the same terms, both of the Canadian Laws Offshore Application Act, and the Territorial Sea and Fishing Zones Act, ibid.

"Marine installation or structure" for this purpose is defined in slightly broader fashion than in the Accord Acts by the inclusion of "dredge, floating crane, pipelaying or other barge or pipeline and any anchor, anchor cable or rig pad used in connection therewith." The Act authorizes expansion of the definition by regulation: Canadian Laws Offshore Application Act, ibid., s. 2.

Supra, note 40 , s. 5(3).

Ibid., s. 6(a). 
Section 7 of the Canadian Laws Offshore Application $A c t,{ }^{44}$ providing for the application of provincial laws in the territorial sea $^{45}$ and on or under marine installations or structures, has not yet been proclaimed. It is to be noted however that the legislation is sufficiently broad to encompass the application of Canadian maritime law, as discussed in greater detail below.

\section{Customs and Excise Offshore Application Act}

The Customs and Excise Offshore Application Act, ${ }^{46}$ originally passed in 1983, extends the application of federal customs laws to goods being imported for use in continental shelf resource production.

This legislation extends to designated goods, which are defined to include ships, drilling rigs, drilling ships, production platforms, storage vessels, pipelines and virtually all equipment associated with offshore exploration and production. This extension of jurisdiction is significant because of the high (often 25 percent) duties which continue to apply to importation of ships and floating equipment. ${ }^{47}$ In this context, it is important that companies consider, at the earliest possible stage, any options which may exist for remission of duties under federal laws. ${ }^{48}$

\section{Specific Offshore Application of Legislation}

Various federal legislation is, by its terms, extended to apply to the offshore area. Examples include the National Energy Board Act, ${ }^{49}$ environmental statutes ${ }^{50}$ and, not surprisingly, taxing statutes. ${ }^{51}$

\section{The Hibernia Legislation}

Concurrent with the conclusion of the development agreements for the Hibernia project in the fall of 1990, the federal government enacted a special Hibernia Development Project $A t^{52}$ which not only applied federal legislation covering banking, debt instruments, bankruptcy and insolvency to this offshore project but also applied Newfoundland legislation affecting security instruments and interests including

Ibid.

Ibid.

R.S.C. 1985 , c. C-53.

Customs Tariff, R.S.C. 1985 (3d Supp.), c. 41, s. 138, Schedule 1, c. 89, S.C. 1987, c. 49 [hereinafter Customs Tariff]. Note that duty payable on goods originating in the U.S. is gradually reducing pursuant to the Free Trade Agreement.

Remission may be granted under the authority of s. 101 of the Customs Tariff, ibid. and the Financial Administration Act, R.S.C. 1985, c. F-11, s. 23. See e.g. D.V. Balmoral Sea Remission Order, SOR/93-91; LASMO Drilling Rig Remission Order, SOR/92-239.

R.S.C. 1985, c. N-7 [hereinafter NEB Act].

See e.g. Canadian Environmental Assessment Act, S.C. 1992, c. 37 [hereinafter CEAA]; Fisheries Act, R.S.C. 1985, c. F-14; Transportation of Dangerous Goods Act, R.S.C. 1985, c. T-19.

Income Tax Act, R.S.C. 1985 (5th Supp.), c. 1 (as to income taxes); Excise Tax Act, R.S.C. 1985, c. E-15 (as to goods and services tax).

S.C. 1990 , c. 41. 
provincial legislation governing bills of sale, registration of deeds and assignment of book debts as if the project was situate within the territorial limits of Newfoundland. It is important to note that these legislative provisions are sufficiently broad to deal with commercial agreements for future production facilities in offshore Newfoundland.

The Hibernia project legislation provides that the Governor in Council may in future, by regulation, restrict or add to the laws applicable to the offshore area. The Terra Nova project may be the first opportunity to determine how government intends to treat such issues, particularly considering that the proposed floating production system is of a maritime nature and will likely bring federal maritime laws generally into play.

\section{CANADIAN MARITIME LAW AND THE OFFSHORE}

The offshore regime is further complicated by the necessary application of Canadian maritime law in certain situations. Oil and gas practitioners have been aware for some time that there are maritime law implications to the conduct of certain exploration and production activities in the offshore area. There is now little doubt that mobile offshore drilling units which float, and which are typically registered as ships under the Canada Shipping $A c t^{53}$ or equivalent legislation in other jurisdictions, will be considered to be ships and thus will be subject to maritime law, except where the legislation expressly excludes such application.

The application of Canadian maritime law can arise by virtue of the Canadian Laws Offshore Application Act, ${ }^{54}$ by the specific extension of Canadian laws applicable to shipping to the offshore and by the application of conflict of laws principles.

\section{What is Canadian Maritime Law?}

The most recent and important development in this area in recent years has resulted from a line of Supreme Court of Canada decisions ${ }^{55}$ within the past ten years which have held that Canadian maritime law is a body of essentially exclusive federal law uniformly applicable throughout Canada. The constitutional basis is subsection 91(10) of the Constitution Act, $1867^{56}$ assigning legislative competence to the federal government in matters respecting shipping and navigation.

It is now reasonably well-settled that Canadian maritime law includes those federal statutes of general application to matters of shipping and navigation, together with the common law of England applicable to maritime matters as it existed in $1934 .^{57}$ Areas

Supra note 30.

Supra note 40.

ITO-International Terminal Operators v. Miida Electronics, [1986] I S.C.R. 752 [hereinafter Miida Electronics]; Q.N.S. Paper v. Chartwell Shipping, [1989] 2 S.C.R. 683; Whitbread v. Walley, [1990] 3 S.C.R. 1273; Monk Corp. v. Island Fertilizers Lid., [1991] I S.C.R. 779 [hereinafter Monk Corp.].

(U.K.), 30 \& 31 Vict., c. 3.

See the definition of "Canadian Maritime Law" contained in the Federal Court Act, R.S.C. 1970

(2nd Supp.), c.10, s. 2 and the discussion in Miida Electronics, supra note 55. 
of greater controversy are the extent, if any, that provincial laws may be applied in this context and whether the applicable common law tort principles are frozen in time (as they existed in England in 1934) or are those that have evolved in a modern context.

However, this overlay of Canadian maritime law does not affect most aspects of the regulatory regime contained in the Accord Acts.

\section{When Will Canadian Maritime Law Apply?}

The test is whether the circumstance in issue is so integrally connected to shipping and navigation so as to be within the federal legislative competence. ${ }^{58}$ The test is easy to state, but can be difficult to apply.

A reasonable starting point in analysis of a particular circumstance is to address the issue of whether or not there are ships involved. As previously discussed, it can now be safely assumed that mobile offshore drilling units, so long as capable of floating, will be considered to be ships for this purpose. The key is the ability to float and to be used in navigation. Thus an offshore jacket platform or a CALM buoy or a subsea pipeline - which are either not floating, not mobile or both - will likely not attract maritime law despite their very maritime nature.

Assuming there are "ships" involved, a reasonable but not exhaustive guide of matters considered covered by maritime law is contained in s. 22 of the Federal Court $A c t^{59}$ where a specific series of matters are enumerated in which the Federal Court of Canada will be considered to have jurisdiction by virtue of its jurisdiction in all cases in which a claim for relief is made or a remedy is sought "under or by virtue of Canadian maritime law or any other law of Canada relating to any matter coming within the class of subject of navigation and shipping." Such areas include:

(1) claims in respect of damage sustained by or loss of a ship;

(2) claims in respect of carriage of goods on board a ship;

(3) claims in respect of loss of life or personal injury occurring in connection with the operation of a ship;

(4) claims in respect of an agreement relating to the use or hire of a ship "whether by charterparty or otherwise" (note that this may therefore be argued to include drilling contracts for offshore units);

(5) claims arising out of a contract relating to the "construction, repair or equipping of a ship"; 
(7) claims in respect of wages or benefits arising from employment of persons on board the ship.

It is beyond the scope of this article to attempt any exhaustive listing of circumstances where Canadian maritime law is likely to apply. It is to be noted that the courts have shown a reluctance to segregate the oil drilling and production aspects of operation of offshore units from the navigational aspects. For example, the Newfoundland Supreme Court has held Canadian maritime law to be applicable to a products liability case arising from the supply during construction of flammable environmental pipe wrapping to a component of the drilling systems on the semisubmersible rig Bow Drill 3. ${ }^{60}$

\section{What Difference Does it Make?}

The applicability of Canadian maritime law, including statutes of general application to shipping, has a number of consequences:

(1) As a result of categorization of offshore drilling units as ships, various consequences flow under Canadian federal legislation including:

(a) application of regulatory statutes including the Coasting Trade Act; ${ }^{61}$

(b) application of the Canada Shipping $A c t^{62}$ and mandatory registration and ship safety thereunder, ${ }^{63}$ and

application of statutory provisions in relation to liability issues including the limitation of liability provisions of the Canada Shipping $A c t^{64}$ and, potentially, the Carriage of Goods by Water Act. ${ }^{65}$

Bow Valley Husky, supra note 58.

${ }^{61}$ S.C. 1992, c. 31 . The coasting trade regime is of enormous commercial importance to the offshore oil and gas operations. Coasting trade is defined to include the engaging by ship in "marine activities of a commercial nature that are in relation to the exploration, exploitation or transportation of the mineral or non-living natural resources of the continental shelf" and the carriage of goods by ship "from one place in Canada or above the continental shelf to any other place in Canada or above the continental shelf" in respect of natural resource development. Supra note 30.

This aspect is of particular significance where ships are employed in the production and storage systems as has been the case in the Cohasset project and will likely be the case for Terra Nova. A jurisdictional overlap occurs between the Department of Transport administering the extensive ship safety regulatory scheme and the offshore boards who have regulating responsibility for installations in the field. This has lead, on Cohasset, to the entry into a detailed memorandum of understanding between the CNSOPB, the Department of Transport and the federal and provincial governments.

Supra note 30. Sections 574-84, providing for a limit of liability dependent on the tonnage of the ship in respect of damage, including personal injury, resulting from operation of the ship so long as the accident has occurred without the "actual fault and privity" of the owner. There is extensive jurisprudence on this issue. 
(2) In the context of asset financing, applicability of the registration and marine mortgage provisions of the Canada Shipping Act. ${ }^{66}$

(3) In the context of claims arising, applicability of the procedural remedies afforded by the Federal Court $A c t^{67}$ in relation to ships which can in certain circumstances lead to commencement of actions in rem against the ship and arrest of the ship.

(4) Application of other maritime law principles. Examples include application of the law of salvage and application of recognized principles of interpretation, and inclusion of implied warranties, in respect of contracts for hire of a ship.

(5) One potentially significant difference arises in liability situations where fault is borne by both parties. The argument has been advanced, as in the Bow Drill 3 litigation previously referred to, ${ }^{68}$ that Canadian maritime law continues to incorporate the absolute bar against recovery in cases of contributory negligence which was part of the common law of England in 1934. In that case, the Newfoundland Court of Appeal recognized the application of provincial contributory negligence statutes which negated the absolute contributory negligence bar and, in the alternative, recognized that the common law has evolved such that it does not now include an absolute bar of recovery in cases of contributory negligence. Leave to appeal to the Supreme Court of Canada on this and various other issues was granted on May 2,1996. ${ }^{69}$

While all of this may sound somewhat complex, the day to day implications in respect of liability issues will not be significant so long as parties drafting contracts and purchasing insurance understand the legal regime in which they are operating. From a regulatory standpoint, the implications can be significant because of the many legal and regulatory requirements applicable to ships and shipping.

\section{Floating Production Systems}

Future production, especially offshore Newfoundland, is anticipated to involve floating production systems with floating drilling platforms as well as adjacent floating storage facilities. It is anticipated that all such systems would be considered by the courts to be ships and subject to Canadian maritime law. It is in this context that the principles of Canadian maritime law may have significant impact, particularly where there is potential overlap and/or conflict between Canadian shipping legislation and

S.C. 1993, c. 21.

Supra note 30 , ss. 6-54.

Supra note 57.

Supra note 58.

Pending final word on the contributory negligence issue from the Supreme Court of Canada, some consideration has been given to proposed federal contributory negligence legislation eliminating the absolute bar. However, it is unlikely that the issue will be resolved legislatively in the near future. 
pollution prevention legislation with the otherwise comprehensive Accord Acts regimes. ${ }^{70}$ In the absence of specific legislative amendment, the financing and security structures applicable to floating systems in Terra Nova and other projects may be significantly different than the commercial arrangements for Hibernia which treated the platform essentially as if it was moveable personal property in accordance with the Hibernia Development Project Act."

\section{E. SUMMARY}

In piecing together the puzzle of the offshore regulatory and legal regimes, practitioners should be cautious that the area continues to develop rapidly. New legislation is anticipated. ${ }^{72}$ There are broad regulation-making powers in certain statutes $^{73}$ which, if exercised, can have significant impact. One important case remains before the courts ${ }^{74}$ and most issues have not received judicial consideration.

With some caution, we summarize the present status as follows:

(1) The key regulators are the CNOPB and CNSOPB who deal with safety, environment, resource management, rights management, and industrial benefits issues pursuant to the Accord Acts regime.

(2) Neither federal nor provincial statutes apply to the offshore (beyond the territorial sea) absent specific federal legislative provision extending their application to the offshore.

(3) Under the Accord Acts, provincial "social legislation" applies to marine installations in the offshore. However, trade union legislation will only apply if the structure in question will be permanently attached to or anchored to or resting on the seabed or subsoil. Provincial consumption taxes are potentially applicable.

(4) With respect to offshore Newfoundland, federal financial legislation applies as does Newfoundland provincial legislation affecting security instruments and interests.

(5) Under the Canadian Laws Offshore Application Act, ${ }^{75}$ federal laws generally apply to marine installations or structures attached to or anchored to the Continental Shelf for natural resource exploration or development. Similar provisions respecting generalized application of provincial laws have not yet been proclaimed.

See note 39 for one example of the interaction between shipping legislation and the Accord Acts. Supra note 52.

Oceans Act, supra note 40.

See e.g. Canadian Laws Offshore Application Act, ibid.

Bow Valley Husky, supra note 58.

Supra note 40. 
(6) The Customs and Excise Offshore Application Act $^{76}$ extends the reach of Canada's customs laws to the continental shelf in connection with natural resource production.

(7) Various other federal laws are extended to the offshore area by virtue of specific provision contained in such laws. Examples include the $N E B$ Act, ${ }^{77}$ tax statutes and environmental statutes. ${ }^{78}$

(8) Where ships are involved, Canadian maritime law may apply by virtue of the Canadian Laws Offshore Application $A$ At $^{79}$ (or its proposed successor, the Oceans $A c t),{ }^{80}$ extension of applicable laws to the offshore areas or application of conflict of laws principles.

\section{THE ONSHORE REGULATORY REGIME}

\section{A. WESTERN NEWFOUNDLAND OIL}

\section{Introduction}

With the upsurge of activity in western Newfoundland, Newfoundland's onshore petroleum regulatory regime is coming to life.

Since 1994, three onshore wells have been drilled on the Port au Port Peninsula in western Newfoundland. Port au Port No. 1 well was drilled for Hunt Oil and PanCanadian in September 1994 and terminated in August 1995. Long Point M-16 well was drilled by the same owners in September 1995 and abandoned in January 1996. Drilling of the Long Range A-09 well for Talisman Energy commenced in February 1996. The Rowan Gorilla IV Jack-up Rig has been engaged and is currently being mobilized to drill the fourth well, St. George's Bay A-36 on the Hunt Oil/PanCanadian offshore license E.L. 1021 adjacent to the Port au Port Peninsula.

As previously noted, under the Newfoundland Accord Acts, the Newfoundland offshore area begins at the low water mark of the Province of Newfoundland and Labrador. Drilling activity on the seaward side of this line is governed by the Newfoundland Accord Acts administered by the CNOPB. Drilling on the landward side of the line, including on submerged areas within the territory of the province, is governed by the Newfoundland Petroleum and Natural Gas Act ${ }^{81}$ administered by the Newfoundland Department of Mines and Energy.

Supra note 46.

Supra note 49.

Supra note 50 and note 51 .

Supra note 40.

Ibid.

R.S.N. 1990, c. P-10 [hereinafter Petroleum and Natural Gas Act]. 


\section{Rights Regime}

The Newfoundland and Labrador Petroleum Regulations, $1991^{82}$ promulgated under the Petroleum and Natural Gas Act prescribe three classes of oil and gas rights, namely:

(1) exploration licenses, which confer non-exclusive rights to conduct an exploration survey, meaning a geological/petroleum survey (not including exploratory wells) directed to the discovery or development of petroleum pools (Exploration licenses are valid for $\mathbf{1 8 0}$ days, and may be renewed for a further term of 180 days. $)^{83}$

(2) exploration permits, which confer upon a permittee for a term of five years, renewable for an additional term of two years (and further renewable if the permittee is in the course of drilling a well upon the scheduled expiry time):

(a) the non-exclusive right to an exploration license in the permit area,

(b) the exclusive right to drill and test for petroleum in the permit area, and

(c) the exclusive right to convert all or any part of the permit area to a lease, ${ }^{84}$

and

(3) leases, which confer exclusive development rights pursuant to approved development plans for a term of two years. ${ }^{85}$

As a practical matter, the Newfoundland Department of Mines and Energy has to date issued only exploration licenses and exploration permits under the Petroleum Regulations. Although the area covered by exploration permit No. 93-102 issued to Hunt Oil Company has been designated under the Petroleum and Natural Gas Act as a development area, ${ }^{86}$ no leases have as yet been issued under the provincial legislation.

The Petroleum Regulations contemplate that the Minister of Mines and Energy may convene public hearings in relation to the issue of oil and gas rights or in relation to any development plan (required to base an application for a lease). To date, such a hearing (or public information session, as it was termed) has been conducted only in relation to the Hunt Oil Company west coast Newfoundland exploratory drilling. Departmental personnel indicate that the requirement for a public hearing will be

Nfld. Reg. 22/91 [hereinafter Petroleum Regulation].

Ibid., s. 10.

Ibid., s. 24.

Ibid., ss. 39-46.

Port au Port Peninsula Petroleum and Natural Gas Development Area Order, Nfld. Reg. 64/95. 
assessed on a case by case basis, but is more likely to be directed in cases of exploratory wells, development area declarations and production operations.

\section{Inter-Jurisdictional Issues}

One of the most interesting legal issues relating to western Newfoundland oil and gas interests is that of the regulation of onshore-to-offshore exploratory wells. To date, four offshore exploration licenses have been issued offshore west coast Newfoundland by the CNOPB. With the March 1996 closing of the request for bids issued by the province's Minister of Mines and Energy, it is anticipated that a total of thirteen exploration permits on onshore areas adjacent to these offshore licenses will be issued under the Newfoundland Petroleum and Natural Gas Act.

With ongoing advances in directional drilling technologies, there is obvious attraction for lower-cost land-based directional drilling of offshore targets. West coast Newfoundland is optimally suited for such onshore-to-offshore exploratory wells.

There is no provision in the governing legislation for onshore-to-offshore exploratory wells. Such wells are technically "inter-jurisdictional" in nature, in the sense that the Department of Mines and Energy has jurisdiction in respect of land-based activities and the CNOPB has sole authority to deal with exploration respecting targets in the Newfoundland offshore area. Oil and gas exploration companies considering land-based directional drilling of offshore targets will accordingly be required to comply with the permitting procedures under both the Newfoundland Accord Acts and the Newfoundland Petroleum and Natural Gas Act. Happily, the CNOPB and the Department of Mines and Energy have been constructive in implementing an approval process for such interjurisdictional wells. To date, approvals have been issued for two land-based exploratory wells associated with offshore targets. These are the Long Point M-16 (Hunt Oil) and Long Range A-09 (Talisman) exploratory wells.

Both the Newfoundland Accord Acts and the Petroleum and Natural Gas Act require an operator to apply for and receive an approval to conduct an exploratory drilling program and an approval to drill each proposed exploratory well. These requirements will apply to inter-jurisdictional drilling applicants.

Exploratory drilling program approvals are based on an operator's technical and operational submission covering such matters as the general location of proposed exploratory wells, the identification of the rig and personnel for the program, the operational and safety procedures proposed and contingency plans. An application for approval to drill a well is a well-specific submission which includes details such as the specific well location, timing, proposed casing program and related technical detail, the proposed depth of the well, the well prognosis and testing program contemplated.

Generally speaking, the permitting requirements relevant to inter-jurisdictional wells are similar under both the Newfoundland Accord Acts and the Petroleum and Natural Gas Act. An operator considering an application for approval for an inter-jurisdictional exploratory well based onshore with an offshore target should nevertheless be aware 
that there are three notable requirements under the Newfoundland Accord Acts permitting process which are unnecessary under the Petroleum and Natural Gas Act, namely:

(1) An operator will be required to submit a Canada-Newfoundland benefits plan respecting the proposed drilling operations;

(2) A declaration of fitness for the equipment and installations to be used in the drilling operations must be provided by the applicant or the owner of such equipment and installations; and

(3) The applicant must provide a maritime-based certificate of fitness from a certifying authority for the drilling equipment or installation to be used in the drilling program.

A fourth significant difference in the two permitting processes relates to the financial responsibility requirements administered by both the Newfoundland Department of Mines and Energy and the CNOPB. Under the provincial legislation, proof of financial responsibility for work commitments and drilling contingencies is discretionary. Practically speaking, the Department of Mines and Energy will require proof of financial responsibility for substantial seismic programs and prior to drilling exploratory wells. Under the Newfoundland Accord Acts, the financial responsibility requirement is mandatory and an operator must, in particular, meet the financial responsibility requirements of the CNOPB respecting environmental risks associated with a drilling program. ${ }^{87}$ In practice, the CNOPB requirements are viewed as more onerous.

As a matter of practice, CNOPB and Department of Mines and Energy personnel have developed an informal protocol, used in the Long Point M-16 (Hunt Oil) and the Long Range A-09 (Talisman) permitting process, whereby a joint review is made of an applicant's separate drilling approval applications. The intent is to streamline the permitting process and to assure that an applicant does not effectively undertake two parallel application procedures with potentially inconsistent requirements. The applicant in this joint review process receives comments on the application materials issued jointly by CNOPB and Department of Mines and Energy personnel.

Departmental personnel advise that the process appears to work smoothly. It will doubtless improve in practice. One area of unusual challenge has been the mandatory requirement under the Newfoundland Accord Acts that an applicant for drilling authorization provide a Certificate of Fitness from a certifying authority. Certifying authorities, as contemplated in the Newfoundland Accord Acts, are those maritime classification societies and marine surveyors whose expertise and experience is in gauging the compliance of offshore rigs with international offshore operations standards. Departmental personnel advise that the surveyors have been constructive in modifying the certification process to accommodate onshore rigs, and that this hurdle has been overcome in a practical and time-effective manner. 
Another area of practical integration of the CNOPB and provincial regime for interjurisdictional wells has been in relation to work obligations under offshore exploratory licenses and onshore exploratory permits. Double counting of exploration expenditures will not be permitted, and an interest-holder seeking to apportion such expenditures as between commitments under an offshore license and an onshore permit will require justification to support any suggested allocation.

Needless to say, the existence of the informal protocols is helpful but interjurisdictional interest-holders drilling from onshore will have justifiable concern as to the incorporation of offshore-based regulatory obligations which typically involve considerably greater financial burdens than do land-based drilling operations.

As with the exploration regime, the Newfoundland Accord Acts and Petroleum and Natural Gas $A c t^{88}$ are silent on the matter of inter-jurisdictional discovery or production wells. There is one curious provision in the Petroleum Regulations ${ }^{89}$ which deals with the case of an inter-jurisdictional petroleum discovery which straddles the low water mark boundary line which divides jurisdiction between the Department of Mines and Energy and CNOPB. In such a case, s. 5 of the Petroleum Regulations provides that the minister will, following consultation with the interest-holder, undertake reasonable efforts to conclude such agreements as may be necessary to assure the province's "administrative co-operation" in the development and production of the discovery. It seems that such limited comfort as may be afforded by this provision relates only to the true "straddling" discovery and not to the inter-jurisdictional discovery situation in which the reservoir is fully within the offshore area but may be produced from a land-based production installation. Moreover, to the extent that this provision (which has no comparable provision in the Newfoundland Accord Acts regime) suggests that the province will defer to the CNOPB's production regime, this reinforces the concerns of interest-holders that the more onerous offshore targeted regulatory obligations may be applied to an onshore production of such a "straddling" discovery.

Such inter-jurisdictional wells or the legal issues presented by the true straddling discovery raise a host of unsettled legal questions ranging from licensing compliance through environmental considerations and even the applicable royalty regime.

A major unsettled issue is the question of what royalty regime might apply to an exploratory well spudded onshore but encountering a reservoir of hydrocarbons in a location offshore, i.e. beyond the low water mark. The answer appears to be practically simple since the jurisdiction over royalties is essentially in the hands of the Newfoundland government either under the Newfoundland Accord Acts regime or the Petroleum and Natural Gas Act onshore regime. Yet considerable uncertainty exists since the province announced a proposed onshore royalty regime in 1994 before "interjurisdictional" drilling programs commenced in earnest and indicated the existence of significant quantities of hydrocarbons. The problem is that, with the exception of 
legislation specific to the Hibernia Project, ${ }^{90}$ the province has no legislated offshore royalty regime for the Grand Banks or the western Newfoundland offshore region. Given that the promising targets to date appear to be located beyond the low water mark within the domain of the offshore regulatory regime, the applicable royalty regime in western Newfoundland is expected to be an offshore one which the province expects will differ from the current onshore scheme. This position of the province is somewhat puzzling given its 1994 public statement that its proposed onshore royalty structure will be modelled on the contractual Hibernia royalty regime and also the regime applied by the federal government to federal lands. ${ }^{91}$

There are other interesting legal issues that are emerging in the area of interjurisdictional drilling and production. If a blow-out occurs in an offshore reservoir affecting a well spudded onshore one wonders whether the potential liabilities would be determined in accordance with the Newfoundland Accord Acts offshore regime or the Petroleum and Natural Gas Act onshore regime. Perhaps both regimes will apply in different circumstances considering that a damaged casing may result in escape of hydrocarbons into the seabed creating marine pollution issues while causing further problems at the onshore drill site which may present land-based pollution issues. The prospect of overlapping jurisdictions may lead to a repeat of the multi-regulatory overlap that manifested itself in such a chaotic way in the investigative and short term regulatory process after the 1982 sinking of the "Ocean Ranger."

Many questions remain in western Newfoundland. Assuming that the western Newfoundland offshore targets prove more productive than land-based prospects, which regulatory regime could be best suited to administer and govern downstream issues applicable to inter-jurisdictional production wells? Is it possible, or even desirable, that the CNOPB and the Newfoundland government might ultimately decide to join forces and allow the more advanced and comprehensive Newfoundland Accord Acts regulatory regime to apply to the exploration and production of hydrocarbon from reservoirs offshore western Newfoundland regardless of where the wells were spudded? Would industry object to the more onerous offshore regulatory regime? Could there even be a constitutional issue arising from what would effectively be an attempted delegation by Newfoundland to a federal-provincial regime of shared jurisdiction by agreement instead of legislation since the Newfoundland Accord Acts regime by law only governs activities beyond the low water mark? A new mirror legislative regime similar to the Newfoundland Accord Acts may be required to bring legal certainty to the applicable regulatory regime to cover the western Newfoundland inter-jurisdictional areas.

Oil Royalty Regulations, Nfld. Reg. 22/96, under the Petroleum and Natural Gas Act. These regulations prescribe a I percent basic royalty respecting production under pre-April 1, 1990 petroleum leases, and confirm that no incremental royalties are exigible in respect of such preApril 1, 1990 petroleum leases. No petroleum leases have in fact been issued under the Petroleum and Natural Gas Act, and these regulations are simply promulgated to be complementary to the statutory royalty applicable to the Hibernia Project under the Newfoundland Accord Act. See the detailed discussion of royalty regimes in Part IV of this article. 


\section{B. COAL BED METHANE IN NOVA SCOTIA}

1. Introduction

Conventional onshore oil and gas exploration in Nova Scotia has been generally both uneventful and unsuccessful. However, Nova Scotia contains a number of carboniferous coal basins with significant coal gas producing potential. The primary areas of interest are the Cumberland Basin, the Stellarton Basin and the Sydney Basin.

There are currently two sets of rights which are being actively pursued for coal gas in Nova Scotia. An exploration agreement is currently outstanding in respect of the Cumberland Basin for coal gas exploration and Nova Scotia's first coal gas production agreement has been awarded in respect of the production of coal gas from a large portion of the Stellarton Basin.

Onshore petroleum exploration and production is regulated in Nova Scotia by the Petroleum Resources $\mathrm{Act}^{92}$ and regulations. All petroleum in the province is deemed to have always been vested in the provincial crown. ${ }^{93}$ Under the Petroleum Resources Act, petroleum includes coal bed methane or coal gas. Commercial exploration and production rights are granted by exploration licenses, coal gas exploration agreements and coal gas production agreements. Pursuant to government policy, coal gas activity is administered by the Petroleum Resources Section of the Department of Natural Resources pursuant to the department's published "Coal Bed Methane Policy."

The realities of coal continue to reign in Nova Scotia. Pursuant to the Petroleum Resources Regulations, ${ }^{94}$ the Minister of Natural Resources is authorized to order suspension or amendment of coal gas exploration or production activities which may adversely affect the activities of a coal rights holder.

Without a coal gas exploration agreement or an exploration license, exploration for coal gas is prohibited. Similarly, only holders of a coal gas production agreement may develop or produce coal bed methane.

\section{Exploration Licenses}

Exploration licenses issued pursuant to the Petroleum Resources Act are nonexclusive rights to explore for petroleum and are intended to enable holders to carry out preliminary exploration. Since such rights are non-exclusive, they do not confer any interest in the lands and other license holders are free to explore the same area. Exploration licenses are issued for a term of one year. Holders may not drill a well deeper than ninety metres. 


\section{Exploration Agreements}

Coal gas exploration agreements issued pursuant to the Petroleum Resources Act grant the exclusive right to explore for coal gas on specific lands and, in addition, provide the holder with the exclusive right to apply for a coal gas production agreement. The initial term for coal gas exploration agreements may not exceed five years. However, where prior to the expiration of the exploration agreement, the drilling of any well has been commenced, the term shall be extended as long as the drilling of that well is diligently pursued. Allowance will also be made for the time required to test and evaluate the well. Notwithstanding these extension provisions, the term can not be extended for more than ninety days. A renewal term for a succeeding term may be granted, however that term may not exceed five years.

Section 17 of the Act requires all holders of the rights, granted pursuant to the Petroleum Resources Act, the Mineral Resources Act, ${ }^{95}$ and the Gas Storage Exploration $A c t^{96}$ which are held in respect of the same or adjacent lands to the lands subject to the exploration agreement application, be notified prior to the government entering into any agreement. All holders of such rights must be given the opportunity to make representations concerning the proposed coal gas agreement.

Within sixty days of applying for an application for coal gas exploration agreement, a notice will be published in the Royal Gazette calling for submission of competing applications. Not less than sixty days following publication of the notice, the Minister of Natural Resources may enter into a coal gas exploration agreement with the applicant who submitted the application which maximizes the general public benefit and the exploration and evaluation of the coal gas potential.

\section{Coal Gas Production Agreements}

Coal gas production agreements confer upon the lessee the exclusive right to develop specified lands for the production of coal gas and the exclusive right to produce coal gas from those lands for commercial purposes. The term of a coal gas production agreement shall not exceed ten years. Nevertheless, the agreement will be renewed for those areas where commercial production is underway. This extension will remain in effect as long as the commercial production of coal gas continues. The agreements can be renewed even if they are not producing gas if, in the minister's opinion, the lands are capable of commercial production. Every coal gas production agreement requires the lessee to carry out a specified development program.

In those instances when an application for coal gas production is received with respect to lands for which a coal gas exploration license was not granted, there are provisions which require publication of a notice and calls for competing applicants. 


\section{Royalty Regime}

All coal gas produced under the authority of coal gas production agreement is subject to a royalty of 5 percent of the coal gas produced each month. ${ }^{97}$ The royalty is based on fair market value of the gas at the surface outlet.

\section{Possible Conflicts}

The lands for which rights have been granted with respect to coalbed methane may also be subject to geothermal rights. For example, in the Cumberland area of Nova Scotia, a geothermal project is currently providing commercial heating, and on the same lands coal gas rights have been issued. A right holder must conduct operations so as not to interfere with or disrupt the reasonable requirements of the other right holder. Clearly, issuing multiple rights for the same lands will lead to legal and operational conflicts. As previously noted, coal rights will be given priority.

\section{FISCAL AND BENEFITS ISSUES}

\section{A. BACKGROUND}

The viability of petroleum exploration and development on the east coast of Canada is clearly subject to the same basic economic considerations that must be analyzed by industry and government in any jurisdiction and which are familiar to most oil and gas practitioners.

In Nova Scotia and Newfoundland, petroleum resources are owned exclusively by government. The government royalty regime will either encourage or discourage petroleum production depending on the degree to which the royalty requirements affect profitability. As a result, government must monitor the various fiscal regimes in force around the world to ensure that they remain competitive in the world market.

While industry and government must both be concerned with the financial viability of a petroleum project, government must also factor in the social and economic benefits for its jurisdiction as a whole. This has led to the Accord Acts requirements for adherence to local benefits principles and the submission of socio-economic impact studies in the submission of development plans to either of the CNOPB and CNSOPB pursuant to the Accord Acts in respect of any proposed oil or gas development in the eastern Canadian offshore area.

On the east coast, oil and gas production is a relatively new phenomenon, at least from a legislative point of view. Although generic royalty regimes are in place in both Nova Scotia and Newfoundland for onshore production, the offshore royalty regimes of both Nova Scotia and Newfoundland have to date been negotiated on a projectspecific basis. Without a known royalty regime, it is difficult for both government and industry to complete a reliable economic analysis of any proposed project. It appears 
that both Nova Scotia and Newfoundland are hoping to remedy this through the introduction of generic royalty regulations applicable to offshore production which will still provide the flexibility for project-specific agreements.

The significance of the equalization offset regime contained in both Accord Acts must also be recognized when discussing fiscal and benefits issues relating to east coast oil and gas development. As the payment of royalties on oil and gas production in the offshore areas of Newfoundland and Nova Scotia will have the effect of reducing equalization payments made by the federal government to those jurisdictions, the equalization offset mechanism is a key component of any royalty equation relevant to proposed developments in the offshore areas of either Newfoundland or Nova Scotia.

\section{B. COMPARISON OF ROYALTY REGIMES}

\section{Nova Scotia Offshore Royalty Regime ${ }^{98}$}

Although pursuant to the Nova Scotia Accord Acts royalties are reserved to Her Majesty The Queen in Right of Canada ${ }^{99}$ the Province of Nova Scotia has the right to establish those royalties pursuant to the Offshore Petroleum Royalty $A c t^{100}$ and will ultimately receive them. The Royalty Act was designed with the intention that the government would produce generic royalty regulations with sufficient detail to allow economic analysis and long-term planning of oil and gas projects in the offshore area of Nova Scotia. However, the Nova Scotia Minister of Natural Resources is granted the power to enter into royalty agreements which are specific to a particular project and which establish any matter which is within the regulatory power set out in the Royalty Act. No generic royalty regulations have yet been passed. Instead the province has entered into a specific royalty agreement for the Cohasset Project and negotiations are currently underway between the government and the proponents of the Sable Offshore Energy Project.

The formula used for royalty calculations under the Cohasset Agreement ${ }^{101}$ combines a fixed share royalty in the early years of the project, with a relatively high net profits royalty later in the project. A gross revenues royalty applies from commencement of production. When invested capital plus current costs have been recovered from gross revenues, the royalty becomes the greater of the gross revenues royalty or a stipulated percentage of net profits. Several amendments to the original royalty agreement have occurred with changes in the project.

The Cohasset Agreement contains certain other incentives which are expected to be unique to the first offshore oil production project in Nova Scotia. For example, the allowable rate of return on operating costs was increased from the usual range of 10

The onshore royalty regime in Nova Scotia was previously discussed in Part III.B, above, "Coal Bed Methane in Nova Scotia."

Nova Scotia Accord Acts, supra note 11, s. 99.

S.N.S. 1987, c. 9 [hereinafter Royalty Act].

LASMO - Province of Nova Scotia Royalty Agreement for CohassedPanuke Project, 1992. 
percent to 25 percent. The costs of abandoning the project at the end of the project are also allowed as project costs. Original estimates of the provincial government were for royalty revenues from the Cohasset Project of more than $\$ 25$ million over the life of the project. ${ }^{102}$ Royalties in excess of $\$ 14$ million have been collected to April 30, $1996 .{ }^{103}$

Royalty returns must be filed by each holder of a share in the production license. ${ }^{104}$ This return must be filed with the provincial government within sixty days of the end of each six-month period with project costs and production resulting in royalties due calculated monthly. ${ }^{105}$ Royalty payments are delivered to the CNSOPB where they are forwarded to the federal government for deposit in the consolidated revenue fund and credited to Nova Scotia. A royalty administration agreement is in place between the province and the federal government and CNSOPB to handle administration and collection of royalty funds.

\section{Newfoundland Offshore Royalty Regime}

At the present time, the offshore royalty regime in Newfoundland is specifically designed to meet the needs of the Hibernia Development Project. Under the Newfoundland Accord Acts, as in Nova Scotia, although royalties from the offshore area are reserved to the federal Crown, ${ }^{106}$ the Province of Newfoundland is the ultimate recipient. A statutory royalty was imposed under the Newfoundland Accord Acts. Subsequently, and in addition, the Newfoundland government and the Hibernia Consortium concluded a royalty agreement in 1991.

While the current Hibernia royalty regime is project specific, it appears that Newfoundland, like Nova Scotia, is considering the implementation of a generic offshore royalty regime through statutory regulation. It is expected that this generic offshore royalty regime will flow from the conclusion of the royalty negotiations on the Terra Nova project and will likely be distinct from both the proposed onshore royalty regime, as discussed below, and the Hibernia regime. As noted previously, ${ }^{107}$ an interesting royalty overlap could arise in respect of wells spudded onshore in western Newfoundland where the reservoir is offshore.

The Hibernia royalty regime, unlike the Nova Scotia (Cohasset) model, consists of two types of royalties: a statutory royalty and a contractual royalty. The statutory royalty is based upon a one percent per barrel charge. The royalty is initially paid to the Government of Canada and then transferred to the province. The statutory royalty is a credit against the contractual royalties payable.

Nova Scotia, Department of Natural Resources, Information Circular No. 26, The Cohasset Project (1992).

Information provided by CNSOPB.

Supra note 102, art. 5.

Nova Scotia Accord Acts, supra note 11, s. 97.

Newfoundland Accord Act, supra note 11, s. 97.

See Part III.A.3, above. 
Under the contractual royalty agreement, each member of the Hibernia consortium is to pay the province a royalty based on production. The contractual royalty consists of three components: gross royalty, net royalty and supplementary royalty:

(1) Gross Royalty. The gross royalty is a percentage of transfer revenue, where transfer revenue is equal to gross sales revenue minus tanker project costs of service. After the cumulative oil production reaches a threshold figure, the gross royalty increases incrementally to a stipulated maximum percentage. In addition, an indexing provision was included for the years in which the Hibernia consortium is repaying certain loans guaranteed by the Government of Canada. When crude oil prices are below an established level the gross royalty payable to the province will be reduced by the proportion that the price of Hibernia crude is below the established level.

(2) Net Royalty. A net royalty based upon the greater of the maximum gross revenue royalty or a percentage of the net transfer revenue is payable when project pay out is achieved. Project pay out occurs when the total cumulative costs, including a stipulated return allowance, equal cumulative gross transfer revenue for the project.

(3) Supplementary Royalty. The supplementary royalty was designed so that the provincial government would receive a progressively higher share of Hibernia profits if the project became very profitable. The supplementary royalty is a percentage of net revenue in addition to the net royalty described above.

In summary, before pay out there is a low rate royalty percentage of gross revenues followed by a higher net profit share following pay out. If the project becomes extremely profitable, the royalty increases significantly.

\section{Newfoundland Onshore Royalty Regime}

Newfoundland's recently announced onshore royalty system is similar in structure to that applied to Hibernia. The formal policy has been released by way of an Information Bulletin dated June 21, 1994. Government officials have indicated that regulations are currently being drafted and will be implemented shortly.

Pursuant to the proposed onshore royalty structure, there is a royalty holiday at the start of production until two million barrels of oil have been produced. Once production exceeds this amount, a basic royalty based upon the project owner's gross revenue is payable, and an incremental royalty will be activated if certain established economic criteria are achieved. The onshore royalty regime can be summarized as follows:

(1) royalty holiday - two million barrels or equivalent;

(2) basic ad valorem royalty -5 percent of gross revenue; and

(3) two-tier net profit tax: 
(a) Tier $1-20$ percent of net revenue after a rate of return of 5 percent plus the long-term government bond rate;

(b) Tier $2-5$ percent of debt revenue after a rate of return of 15 percent plus the long-term government bond rate.

\section{LOCAL BENEFITS}

\section{Background}

Under both of the Accord Acts, the offshore boards must approve development plans before any work or activity in the offshore may begin. ${ }^{108}$ Development plans are generally required to include all relevant technical information necessary for comprehensive review of the proposed development.

Before a development plan can be approved, a benefits plan must also be approved. ${ }^{109}$ Benefits plans generally outline how the project will be structured so as to provide Canadians, and particularly provincial residents, with a full and fair opportunity to participate in the project. Under subsection 45(1) of the Accord Acts a benefits plan is defined as follows:

45(1) In this section, "Canada-Nova Scotia benefits plan" means a plan for the employment of Canadians and, in particular, members of the labour force of the Province and, subject to paragraph (3)(d), for providing manufacturers, consultants, contractors and service companies in the Province and other parts of Canada with a full and fair opportunity to participate on a competitive basis in the supply of goods and services used in any proposed work or activity referred to in the benefits plan.

The basic local benefits principles are further set out in s. 45(3) and s. 45(4) of the Accord Acts:

45(3) A Canada-Nova Scotia benefits plan shall contain provisions intended to ensure that

(a) before carrying out any work or activity in the offshore area, the corporation or other body submitting the plan shall establish in the Province an office where appropriate levels of decision-making are to take place;

(b) consistent with the Canadian Charter of Rights and Freedoms, individuals resident in the Province shall be given first consideration for training and employment in the work program for which the plan was submitted and any collective agreement entered into by the corporation or other body submitting the plan and an organization of employees respecting terms and conditions of employment in the offshore area shall contain provisions consistent with this paragraph; 
(c) a program shall be carried out and expenditures shall be made for the promotion of education and training and of research and development in the Province in relation to petroleum resource activities in the offshore area; and

(d) first consideration shall be given to services provided from within the Province and to goods manufactured in the Province, where those services and goods are competitive in terms of fair market price, quality and delivery.

45(4) The Board may require that any Canada-Nova Scotia benefits plan include provisions to ensure that disadvantaged individuals or groups have access to training and employment opportunities and to enable such individuals or groups or corporations owned or cooperatives operated by them to participate in the supply of goods and services used in any proposed work or activity referred to in the benefits plan.

It is interesting to note that pursuant to the CNSOPB Industrial Benefits and Employment Plan Guidelines"10 a "resident of Nova Scotia means ... in the case of a corporation, an entity that has an operating office in the Province, that is duly registered with the Registrar of Joint Stock Companies of Nova Scotia to conduct business in the Province and that has as its controlling shareholders residents of the Province." Caution should be exercised in relying upon these guidelines as they are guidelines only and under continuous review by the board. In the comparable Exploration Benefits Plan Guidelines ${ }^{111}$ administered by the CNOPB, a Newfoundland resident is defined to mean "a Canadian (or landed immigrant) who meets the residency requirements of the Province of the Newfoundland Elections Act ... [and] has resided in the province for the immediately preceding six month period." No corporate residency criteria are prescribed.:

Over the life of each project, the offshore boards have responsibility for monitoring the performance of the project members to ensure compliance with all the benefits plan commitments. In both provinces, it is clear that the boards consider the benefits plans to be a significant obligation of the proponents, both at the approval stage and at the benefits monitoring stage.

\section{Experience to Date}

The Cohasset Project is not a major project on a world scale when compared with Hibernia. As it was the first project of its kind in Canada without the basic industrial infrastructure for oil production, certain compromises had to be made to permit project viability. A majority of the equipment was not readily available from Canadian sources and it was necessary to turn to foreign suppliers. The project members initially proposed to lease the major components for the required installations, including the drilling rig/production platform, interfield and export flowlines and the export system. 
After reviewing the initial benefits plan, the CNSOPB felt that there were still a number of potential opportunities for Canadian and Nova Scotia firms. In its benefits plan decision, ${ }^{112}$ a number of conditions were imposed, including the following:

The Proponent shall investigate and pursue all reasonable opportunities to provide for maximum Canadian and, in particular, Nova Scotian participation in the fabrication and assembly of the well-head jackets, production facilities and rig modifications and modifications, if required, in the equipment comprising of the Export system and satisfy the Board that the Proponent's packaging of these contracts, their specifications and terms and conditions (including delivery times) has not disadvantaged Nova Scotian and Canadian bidders.

Extensive local contractor content was added, arguably at considerable additional cost to the project.

The current approach of the CNSOPB on local benefits is to commit proponents to basic principles, particularly "full and fair opportunity" and "first consideration to Nova Scotians" and closely monitor performance rather than mandate specific requirements for the project. To assist with the monitoring of the Cohasset Project the board reviews the award of all major contracts over $\$ 250,000$ at the bidding stage and prior to contract award. Application of local benefits principles, both in the context of award of contracts and hiring of personnel, has been the subject of very extensive dialogue between the CNSOPB and the operators on Cohasset.

The experience to date on the Hibernia project shows that the CNOPB is taking an even more interventionist approach. The CNOPB, as a condition of its approval of the Hibernia benefits plan required that a listing of all major contracts or purchase orders be provided, and the board in consultation with the project members will decide which contracts are subject to review. ${ }^{113}$ In addition, the board is to receive advance notice of and information on contracts or purchases so that the board can review the suitability of the contracts. The board monitors expenditures, employment, job descriptions and required qualifications. Nevertheless, the approach in Newfoundland appears, like Nova Scotia, to be mostly based upon a commitment by the proponent to principles rather than specific requirements. Finally, because of the size of the Hibernia project the board is also concerned about the impact on population, housing, public infrastructure, and social services.

\section{Alliance Contracting}

The oil and gas industry on the east coast appears to be moving towards collaborative relationships for the development of offshore resources. These relationships are often referred to as partnering or alliances. This collaborative approach 
is intended to replace what is often viewed as an adversarial contractor and client relationship with a relationship where responsibility, risk and reward are shared between alliance members which will include the project proponent. It is hoped that alliances will reduce expenses and promote efficient long-term supply relationships. ${ }^{114}$

In the context of the benefits requirements of the Accord Acts, it can be anticipated that the offshore boards and governments will be vigilant to ensure that alliance contracting does not adversely impact small local contractors by making it difficult to participate as alliance members.

\section{Litigation arising from Benefits Commitments}

Oil and gas companies formulating and administering benefits plans should be aware that the provisions of s. 45 of the Accord Acts have already become the basis for litigation commenced by unsuccessful bidders. The underlying principles of the CanadaNewfoundland benefits plans provisions call for a full and fair opportunity for Newfoundland-based contractors and suppliers as well as Canadian-based contractors and suppliers to be provided with opportunities for work on projects covered by that scheme. Threatened and pending litigation has been based upon allegations by unsuccessful bidders that they did not have a full and fair opportunity to bid and secure contracts for the Hibernia project. It has also been alleged in litigation which has since been discontinued that the CNOPB failed to fulfil its mandate by ensuring that any approved development plan will contain sufficient provision to ensure that Newfoundland-based contractors will have a preferential position to obtain contract work.

Unlike other federal statutes ${ }^{115}$ that provide for a civil remedy in the event of a breach of a statutory obligation, the Accord Acts do not provide for any civil remedy to aggrieved third parties arising out of any breach of the Act, whether in respect of Canada-Newfoundland benefits or otherwise.

Absent adjudication of the question of what if any remedies might be available to disgruntled bidders, oil and gas companies planning to submit and implement benefits plans as part of offshore development should be alert to these issues which experience has taught have the potential to put the developing consortium in a four-way confrontation with the disgruntled bidder, the offshore board and senior federal and provincial officials acting through their respective ministers responsible for energy matters in attempting to interpret and enforce the benefits plan.

The three alliance groups which have, as of the time of writing, been invited to make submissions to the operator in respect of development of Terra Nova are: Alliance Newfoundland, Avalon Offshore Alliance and Grand Banks Alliance. It is anticipated that proponents of the Sable Offshore Energy Project will also seek to enter into an alliance with a contractor group. 


\section{APPLICABILITY OF PROVINCIAL TAX REGIMES}

\section{Nova Scotia}

Pursuant to s. 212 of the Nova Scotia Accord Acts, consumption taxes are to be levied and collected in the offshore area as though it were in the land portion of Nova Scotia. Corporate income taxes may also be levied and collected by the province in the offshore as though the offshore were part of the land portion of the province.

In Nova Scotia, the provincial government recently passed the Revenue Act ${ }^{116}$ which amends and consolidates certain consumption tax acts including the former Health Services $\mathrm{Tax}^{\mathrm{Act}}{ }^{17}$ (the provincial sales tax statute) and the former Gasoline and Diesel Oil Tax Act. ${ }^{118}$ Both of these former acts were included in the definition of "Nova Scotia Consumption Tax Acts" under the Nova Scotia Accord Act. Notwithstanding the provisions of the Nova Scotia Accord Acts, s. 14 of the Revenue Act excludes the offshore from provincial sales tax except under certain limited conditions such as tangible personal property purchased upon a regular scheduled ferry that terminates inside the province. In addition, under s. 25 of the Revenue Act, certain classes of tangible property are exempt from provincial sales tax, including "tangible personal property consumed or used in the production or processing of non-renewable resources."

\section{Newfoundland}

Under s. 207 of the Newfoundland Accord Acts consumption taxes are given similar treatment as described above for Nova Scotia. Part II of the Newfoundland Retail Sales Tax Act $^{119}$ deals specifically with the Hibernia Development Project. Designated persons who are defined as project owners, project operators, major contractors and subcontractors (all of whom are defined under the Act) are exempt from tax on certain "eligible items" that were acquired for consumption or use on a Hibernia capital program. In addition, designated persons need only pay a "4 percent tax with respect to eligible items for consumption or use on the project, other than a project capital program." As this tax regime was implemented specifically for the Hibernia project, it is not yet clear what rates will apply to future developments such as Terra Nova.

\section{E. FUTURE DIRECTIONS}

Although the Nova Scotia government has indicated a preliminary intention to establish a generic offshore royalty regime, completion of a royalty agreement specific to the proposed Sable project will deal with the only project currently being proposed for the Scotian shelf. As such it will be interesting to see if the Nova Scotia

\footnotetext{
116 S.N.S. $1995-96$, c. 17.

117 R.S.N.S. 1989 , c. 198.

118 R.S.N.S. 1989, c. 183. This statute was applicable to fuel consumed in offshore production.

119 R.S.N. 1990, c. R-15.
} 
Department of Natural Resources proceeds further with a generic royalty regime in the context of finalization of the Sable royalty agreement.

It is expected that the Newfoundland government will proceed with the implementation of a generic offshore royalty regime, stimulated largely by the high current interest in offshore areas of western Newfoundland. Current indications that the generic offshore royalty regime will be distinct from the royalty regime currently in place pursuant to the Hibernia royalty agreement seem to be somewhat in conflict with the adoption of a Hibernia-like structure as the generic onshore royalty regime which will apply in the onshore areas of western Newfoundland. It will be interesting to see how the Newfoundland government proceeds in the face of this apparent conflict, particularly in light of the possibility that substantial petroleum reservoirs straddle the boundary between offshore and onshore Newfoundland.

\section{SIGNIFICANT DISCOVERY LICENSES UNDER THE OFFSHORE ACCORD REGIMES}

\section{A. BACKGROUND}

Following the repeal of the Canada Oil and Gas Act, ${ }^{120}$ the Canadian Petroleum Resources Act, ${ }^{121}$ upon which the Atlantic Accord ${ }^{122}$ and Nova Scotia Accord ${ }^{123}$ legislative regimes were modelled, provided for three basic types of interests: exploration licenses, significant discovery licenses and production licenses.

Exploration licenses have a fixed term of nine years and, if an interest owner is unsuccessful in making a discovery of hydrocarbons and securing a significant discovery license, the permit area reverts to the Crown.

On the other hand, if an interest owner secures a significant discovery license, the rights arising under the license do not have a limited term and can in fact preserve the area subject to the license until the reserves can be proven to be worthy of production, at which time a production license can be sought and obtained.

The Newfoundland and Nova Scotia offshore regulators have the residual power to order the drilling of wells no sooner than three years after the awarding of a significant discovery license. No more than one well can be ordered to be drilled at any one time. This is less onerous than the draconian provisions that existed under the Canada Oil and Gas Act, ${ }^{124}$ which empowered the minister to compel the drilling of as many as three wells simultaneously on a significant discovery area.

Ibid.

Supra note 9. 
The awarding of significant discovery licenses has been the subject of considerable interplay and litigation between industry and the CNOPB during the last five years. The outcome has been the planned establishment by the CNOPB of more specific guidelines prescribing the type of supporting evidence that is expected to be submitted in future by an interest owner when seeking a significant discovery area declaration and license, and in the setting of new rules of procedure for the actual review process.

At the outset, it is important to understand what comprises a "significant discovery." The Supreme Court of Canada has affirmed the Newfoundland Court of Appeal's finding that "significant discovery" as defined in the Accord Acts regime has four requirements:

(1) a discovery of hydrocarbons;

(2) indicated by the first well on a particular geological feature;

(3) which demonstrates by flow testing the existence of hydrocarbons in the feature; and

(4) which suggests an accumulation of hydrocarbons having the potential for sustained production, as determined by geological and engineering factors. ${ }^{125}$

There has been considerable debate as to the type of evidence in addition to flow testing results that must exist with regard to the fourth requirement for a significant discovery. This debate has included the issue of the appropriate burden of proof to be imposed by the CNOPB upon an applicant for a significant discovery license in view of the relatively speculative nature of developing and interpreting geological and engineering data with respect to an anticipated existence of a reservoir of hydrocarbons which might potentially sustain future production in the offshore.

When the significant discovery provisions in the Accord Acts were considered by the Supreme Court of Canada in Mobil Oil Iacobucci J. wrote for the Court:

Pursuant to s. 44(1) of the Canada Oil and Gas Act, the Minister was invested with significant discretionary authority in respect of SDDs. Out of the current regime, however, this discretion has given way to an objective test which favours industry participants. Whereas the Minister under s. 44(1) had to be 'satisfied' that a significant discovery existed before he 'may' have made a declaration, under s. 71(1), the Board 'shall' make declarations once 'reasonable grounds' have been proved. ${ }^{126}$

Justice Iacobucci referred in his judgment to two of the eight purposes of the Atlantic Accord, namely, "to provide for a stable and fair offshore management regime for industry" and "to provide for a stable and permanent arrangement for the management 
of the offshore." ${ }^{127} \mathrm{He}$ further wrote that an applicant has a right of procedural fairness, because of the significant effect on the applicant's investment if a declaration of significant discovery is not obtained. ${ }^{128}$

Under the Accord Acts, the Newfoundland and Nova Scotia superior courts are given exclusive jurisdiction with regard to judicial review arising from decisions made by the offshore regulators.

\section{B. THE KING'S COVE CASE}

The most recent judicial review of the appropriate criteria for a significant discovery declaration is found in a decision rendered July 27, 1995 by Justice Leo Barry of the Newfoundland Supreme Court in the case of Petro-Canada v. CNOPB, ${ }^{129}$ where he overturned the denial by the CNOPB of a significant discovery license application by Petro-Canada for its King's Cove A-26 offshore well.

Justice Barry held that the CNOPB had erred in applying an incorrect burden of proof. He stated:

It is a reasonable inference from the above references that the Committee and the CNOPB were, at least at times, requiring the Applicants to prove, on a preponderance of probabilities, a likelihood of sustained production rather than just a potential. This is not what section 47 requires. That section only requires the Applicants to establish that information on their 'well' suggests the 'potential' for sustained production of hydrocarbons. ${ }^{130}$

\section{Justice Barry concluded:}

So the statutory language supports the conclusion that the proper burden to impose upon the Applicants is that suggested by Reed, J. in Mobil Oil, namely, require them to show 'reasonable grounds to believe there is a possibility' of sustained production, that is, reasonable grounds to believe sustained production may be practicable. ${ }^{131}$

Justice Barry essentially suggested that an applicant for a significant discovery license has the legal burden of satisfying the regulator by the data, hypotheses and theories presented that it has met the standard of proof required by the legislation. The civil standard applies, that is, proof on the preponderance of probabilities. However, he pointed out the following:

The unusual situation here, however, is that what must be so proved is merely data which 'suggests' a 'potential,' that is, a possibility. The result is that Petro-Canada had to prove the suggestion of a 
possibility on a balance of probabilities, a 'fairly generous test,' in the words of Reed, J. in Mobil Oil, to say the least. ${ }^{132}$

Justice Barry concluded his analysis by suggesting that the regulator is entitled to require applicants for significant discovery licenses to supply reliable data and acceptable scientific hypotheses and theories to explain them. Such data, hypotheses and theories may not, however, be rejected by the regulator merely because doubts are raised regarding them by other available data, hypotheses and theories. These other data, hypotheses and theories must be weighed against the applicants using the expert knowledge available to the regulator. He further held that the regulator must explicitly explain why it is left with no "suggestion" of a "potential" for sustained production after this process has been completed. He found that if the regulator is left with reasonable grounds to believe that there is a possibility of sustained production, that is, grounds based upon unrefuted data, hypotheses and theories, the applicant should obtain a significant discovery declaration. If the data, hypotheses and theories supplied are refuted, then the regulator need not issue a declaration.

Justice Barry referred the matter back to the CNOPB for further consideration. In an ensuing review process which included further technical submissions by Petro-Canada, the CNOPB decided to declare a significant discovery and award a significant discovery license to Petro-Canada.

\section{POSSIBLE FUTURE GUIDELINES}

It is instructive that in the reconsideration process there is a need for the CNOPB to consider developing specific guidelines which would apply to a technical review and assessment of the evidence submitted to supplement the flow testing results when dealing with future applications for significant discovery declarations.

The revised approach which the CNOPB would hopefully include as part of such new evidentiary requirements and rules of procedure be consistent with the decision of Justice Barry can be generally outlined as follows:

(1) The reliability of data, hypotheses and theories submitted will be assessed (i.e. to ensure that they are based on scientific validity, grounded in methods and procedures and science as opposed to speculative belief or unsupported speculation, and generally accepted by the scientific community).

(2) In reviewing the evidentiary material submitted by the applicant, any material which the CNOPB believes should be refuted because it is believed to be unreliable will be identified. However, in so doing, the CNOPB will provide any other evidentiary material which is believed to be relevant and explain the bases and reasons for taking such a position. 
(3) The weight given by the applicant regarding its data, hypotheses and theories, including where applicable the weight given to alternative explanations, will be discussed.

(4) Consideration will be given to all the geological and engineering factors and their relationship to the potential for sustained production including the size and quality of accumulation, and the technology, volume and economics relating to production.

The CNOPB is considering the formulation of a new set of rules of procedure which will be submitted to industry for comment. The specific requirements respecting the type of evidence which the CNOPB may require from applicants for future significant discovery declarations could include: (1) structure maps of particular specifications; (2) available 3-D seismic data and the applicant's interpretative analysis defining the potential reservoir; and (3) stratigraphic cross-sections based on wireline logs and a geological description of the projected reservoir with a stratigraphic correlation and sedimentological model. A further important requirement will be a submission by the applicant as to estimated volumes of in-place and recoverable hydrocarbons including information respecting the technology and economics relating to production, all of which support the potential for sustained production.

\section{REGULATORY AND ENVIRONMENTAL ISSUES PERTAINING TO SCOTIAN SHELF GAS DEVELOPMENT}

\section{A. THE PROPOSED SABLE PROJECT}

Scotian shelf gas development poses unique regulatory challenges. Covering more than 40 million hectares off Nova Scotia, the area is still largely unexplored. The Province of Nova Scotia estimates total gas resources on the shelf to be in the order of 512 billion cubic metres. The majority of discovered gas is in the area surrounding Sable Island, where gas pools are estimated to contain 142 billion cubic metres of recoverable gas.

The currently proposed Sable Offshore Energy Project ${ }^{133}$ would represent the first development of Scotian shelf gas. The project involves six producing fields ${ }^{134}$ which lie ten to forty kilometres north of the southern edge of the shelf.

The onshore, offshore and pipeline components of Sable make it a very different project from a regulatory perspective than any of Hibernia, Terra Nova or Cohasset. For purposes of this discussion, the key project components may be summarized as follows:

(1) Satellite platforms - fixed production platforms, probably of jacket-type construction, at five of the six fields.

\footnotetext{
133 See supra note 5 regarding the project proponents.

134 Venture, South Venture, Thebaud, North Triumph, Genelg and Alma.
} 
(2) Inter-field flow lines - collection lines delivering gas from satellite platforms to the central platforms.

(3) Thebaud platforms - fixed production and accommodation platforms to be located at the Thebaud field.

(4) Offshore pipeline - a pipeline delivering gas from the Thebaud platforms to the gas plant.

(5) Gas plant - slugcatcher and gas plant tentatively sited adjacent to the offshore pipeline landfall at or near Country Harbour, Nova Scotia.

(6) Liquids pipeline - a pipeline for transport of liquid condensate from the gas plant across part of mainland Nova Scotia and under the Strait of Canso to the Point Tupper, Nova Scotia area.

(7) Liquids processing facility - a processing facility for condensate located at or near Point Tupper, Nova Scotia.

A separate market gas pipeline project will deliver gas from the gas plant through Nova Scotia and New Brunswick to market. ${ }^{135}$

\section{B. AREAS OF POTENTIAL REGULATORY JURISDICTION}

It is beyond the scope of this article to exhaustively address the limits of jurisdiction and areas of overlapping jurisdiction in respect of regulation of the Sable project. It is, however, clear that there are three key regulators with potential jurisdiction, the CNSOPB, the National Energy Board ("NEB") and the Energy and Mineral Resources Conservation Board ("EMRCB") of Nova Scotia.

\section{CNSOPB}

As discussed in detail previously in this article, the CNSOPB has principal regulatory authority over the development of oil and gas resources in the Nova Scotia offshore area. The jurisdiction of the board commences with rights issuance, extends through the exploration, discovery and operation stages to completion and abandonment.

In order for a proponent in the position of the Sable Offshore Energy Project ${ }^{136}$ to commence offshore development, it must make application to the CNSOPB for and obtain: ${ }^{137}$

\footnotetext{
13s The proposed pipeline is the Maritimes and Northeast Pipeline Project: sec supra note 6.

136 There are currently significant discovery licenses issued in respect of each of the six Sable fields.

137 Nova Scotia Accord Acts, supra note 11, s. 140; Newfoundland Accord Acts, supra note 11, ss. 137.
} 
(1) an operating license issued pursuant to the Accord Acts; ${ }^{138}$ and

(2) authorizations to undertake proposed work or activity. ${ }^{139}$ Various authorizations will be required at different stages of development. Two key ones are the production authorization and the drilling authorization. ${ }^{140}$

The mandatory operating license required under the Accord Acts is issued on an annual basis, expiring on March 31 of each year.

In order to obtain and maintain the required authorizations, the proponent must:

(1) have received the approval of the CNSOPB of a development plan;

(2) in the absence of waiver by the CNSOPB, have received the approval of the board of the proponent's benefits plan; ${ }^{141}$ and

(3) provide a required certificate of fitness in respect of the proposed equipment and installation.

The development plan is required to include such items as:

(1) a description of the general approach of developing the pool or field;

(2) the scope, purpose, location, timing and nature of development;

(3) production rate, estimated recovery amounts, reserves;

(4) environmental factors;

(5) proposed production system and alternatives; and

(6) such technical and other information and proposals as may be prescribed so as to enable the CNSOPB to conduct a comprehensive review of the proposed development.

Mineral rights at the production stage are obtained by application to the board for a production license which, when issued, confers title to the petroleum produced. As a condition precedent to issuance of the production license, the proponent must have successfully applied to the CNSOPB for a declaration of commercial discovery in relation to the applicable portions of the offshore area. "Commercial discovery" is defined as: 
a discovery of petroleum that has been demonstrated to contain petroleum reserves that justify the investment of capital and effort to bring the discovery to production. ${ }^{1 / 2}$

The ongoing regulatory role of the CNSOPB through the life of project extends to all aspects of the project.

\section{The NEB}

Although the Accord Acts regime contemplates a comprehensive scheme of regulation of offshore projects, there remains an overlap with the jurisdiction of the NEB as created under the NEB Act. ${ }^{143}$ The jurisdiction of the NEB arises out of its regulatory authority in respect of construction and operation of pipelines (part III of the $N E B A c t$ ) and, if direction is made pursuant to s. 124 of the $N E B A c t$, in relation to movement of designated oil or gas out of the offshore area.

Under Part III of the NEB Act, a certificate of public convenience and necessity is required before a company may construct a pipeline. Section 2 of the $N E B$ Act defines "pipeline" as follows:

"Pipeline" means a line that is used or to be used for the transmission of oil or gas, alone or with any other commodity and that connects the province with any other province or provinces or extends beyond the limits of a province or the offshore area as defined in Section 123, and includes all branches, extensions, tanks, reservoirs, storage facilities, pumps, racks, compressors, loading facilities, inter-station systems of communication by telephone, telegraph or radio and real and personal property and works connected therewith.

The "offshore area" as defined in s. 123 includes the Scotian shelf. On this basis the NEB is anticipated to assert joint jurisdiction with the CNSOPB in respect of the offshore pipeline component of the Sable project.

The NEB jurisdiction will apply to such components of the project as come within the statutory definition of "pipeline," subject to the overriding constitutional requirement that the project components form part of an interprovincial work or undertaking. This determination is somewhat difficult having regard to the uncertainties as to the upstream limits of the NEB jurisdiction in gas collection, processing and transmission systems arising from decisions of the NEB and the Federal Court of Appeal in Westcoast Energy Inc. v. National Energy Board and Attorney General of Canada. ${ }^{144}$

142 Nova Scotia Accord Acts, supra note 11, s. 49; Newfoundland Accord Acts, supra note 11, s. 47. 143 Supra note 49.

14 (1996), 134 D.L.R. (4th) 114 (F.C.A.) [hereinafter Westcoast Energy]. In considering the respective jurisdiction of the NEB and CNSOPB, consideration must be given to s. 4 of the Nova Scotia Accord Acts giving the Nova Scotia Accord Acts precedence over any other Act of Parliament that applies to the offshore area. 
Leave to appeal the Westcoast Energy decision to the Supreme Court of Canada has been sought and, if leave is granted, much needed additional clarification on this issue may be forthcoming.

\section{EMRCB (Nova Scotia)}

The EMRCB derives jurisdiction from two Nova Scotia statutes, neither of which has been actively employed since original passage. The Energy and Mineral Resources Conservation $\mathrm{Act}^{145}$ establishes the EMRCB and assumes a broad jurisdiction in relation to the development, production, transmission and transportation of energy and mineral resources. The Pipeline Act $^{146}$ establishes the EMRCB as a regulator in relation to the construction, testing, maintenance and operation of pipelines within Nova Scotia. Broad regulation-making powers are contained in both statutes, each of which purports to also apply to the continental shelf adjacent to Nova Scotia, an assumption which is constitutionally questionable.

\section{ENVIRONMENTAL ASSESSMENT}

The Sable Offshore Energy Project will also be subject to the environmental assessment requirements of various jurisdictions. The required environmental assessment can be divided into the three categories discussed below.

\section{CNSOPB Assessment}

CNSOPB is required to undertake environmental assessment of the project by virtue of its required approval of the development plan and its ongoing responsibility for safety and environmental matters. As part of a public review of a project, the board may require (and will require for Sable) filing of an environmental impact statement and socio-economic impact statement in addition to the development plan and benefits plan.

\section{Federal Assessment}

The required federal environmental assessment of the project arises under the $C E A A^{147}$ which may be triggered by those categories of federal government involvement set forth in s. 5(1) of the Act.

Included among those federal decisions is the grant of a certificate of public convenience and necessity issued under Part III of the NEB Act. Other federal decisionmaking authorities which may be applicable to Sable also invoke the $C E A A$ process. 
The $C E A A$ establishes a multi-stage process for environmental assessment of projects, usually, but not necessarily, commencing either with a so-called screening of the project or a comprehensive study of the project which can in turn lead to the appointment of a review panel to undertake detailed assessment of the project. Mediation is an alternative to panel review under the CEAA. The report of the panel or mediator is ultimately provided to the responsible federal authority.

In addition to the assessment process contemplated by the $C E A A$, the NEB is required by its own processes to undertake assessment of the environmental impacts of a project in the context of its processing of applications for pipeline certificates under Part III of the NEB Act.

\section{Provincial Assessment}

The Environment $A c t^{148}$ of Nova Scotia provides for environmental assessment of "undertakings" with different levels of assessment depending on the nature of the undertaking. Under the Nova Scotia process, a full environmental assessment undertaken by the Nova Scotia Environmental Assessment Board is mandatory in respect of certain class II undertakings (which would not be considered to include the Sable project). ${ }^{149}$ Otherwise, the referral of a project to the Nova Scotia Environmental Assessment Board for public hearing or review is within the discretion of the Minister of the Environment.

\section{THE SABLE SOLUTION}

Time and legislative constraints have prevented the adoption of a true "single window" regulatory and environmental process where a combined regulator issues a single decision in relation to regulatory (or environmental) matters at the end of one regulatory and environmental assessment process. Nevertheless, the regulators, and potential regulators, of Sable have displayed an encouraging willingness to produce a streamlined and coordinated process.

In general, in the several cases of potential jurisdictional overlap, the approach has been to recognize dual jurisdiction of regulators as opposed to attempting to reconcile the competing jurisdictions. The anticipated result is combined regulatory and environmental processes, each covered by separate administrative agreements or memoranda of understanding between the regulators. Neither is finalized at the time of writing, but the anticipated results are as noted below.

\section{Regulatory Matters}

While the proposed agreement has not yet been publicly released, it is anticipated that exercise of regulatory jurisdictions will be undertaken in a coordinated manner by the CNSOPB, NEB and the EMRCB. The applicants will file a single application with 
agreed elements. Each of the regulators will continue to separately exercise their required statutory jurisdictions and render separate decisions as to those matters within their jurisdiction.

\section{Environmental}

The environmental regulators (CNSOPB, NEB and the governments of Canada and Nova Scotia) are headed toward an agreement for a joint public review of the project, and the market gas pipeline project. The Province of New Brunswick, through which the market gas pipeline will pass, is not anticipated to be a party to the agreement.

The nature of the proposed process is indicated by a recital to a draft of the agreement which has been publicly released:

The parties to this agreement undertake to conduct a joint public review for the environmental assessment of the projects described herein with the objective of harmonizing environmental assessment requirements to avoid delay, duplication and overlap, while ensuring that the responsibilities and requirements of each jurisdiction are respected. ${ }^{150}$

A joint five-member public review panel is to be appointed by the CNSOPB, the NEB and the federal and provincial environment ministers. This panel will address all aspects of the environmental public review. The panel chair person is to be a joint nominee of the federal and provincial environment ministers, the CNSOPB and the Chairman of the NEB. Two members will be permanent members of the NEB and, together with the chair, will constitute the NEB panel for purposes of the NEB regulatory jurisdiction. One of the other panel members will serve as a Commissioner reporting to the CNSOPB for purposes of that board's public review of the development and benefits plans.

The review will include two categories of hearings, one of which will be a more formal "NEB-type" hearing. The hearings will be designed to facilitate public participation and participant assistance will be provided through the existing program of the CEAA. A deadline is established pursuant to which the panel report is to be delivered within $\mathbf{2 7 0}$ days from the date of delivery of the required information to the panel after which each of the regulators have a further sixty day period in which to make their respective decisions.

\section{Terra Nova Environmental}

A similar and encouraging degree of cooperation appears to be emerging in connection with environmental assessment of the Terra Nova Development Project on the Newfoundland continental shelf. 
The regulatory and environmental assessment regimes applicable to Terra Nova are less complex because of the absence of NEB jurisdiction and the reduced provincial environmental assessment responsibilities. As a result, the key environmental regulators are the CNOPB and the federal minister of the Environment by virtue of the Minister's responsibilities under the CEAA. As of the time of writing, a proposed agreement in respect of joint public review of the project has been released. The draft agreement contemplates a joint panel environmental assessment hearing to undertake the environmental review required by the CNOPB and to perform the function of a review panel appointed pursuant to the $C E A A$.

It is noteworthy that although the draft agreement contemplates the exemption of the project from the Newfoundland Environmental Assessment $A c t,{ }^{151}$ the provincial minister does reserve the right to impose terms and conditions upon project approval.

\section{CONCLUSION}

Although the legal regime applicable to east coast development is substantially defined, some jurisdictional uncertainty remains. The recent surge in activity, both in exploration and with the advent of producing projects, will result in further clarification and further evolution over the next few years.

By its very nature, development on the east coast, particularly in the offshore, raises interesting and sometimes difficult legal and regulatory issues. The offshore boards and the Accord Acts remain new to the Canadian oil and gas industry. An overlay of maritime law keeps things interesting.

One of the key factors in the development equation will be the presence of reasonable but effective regulatory processes and the creation of a fiscal and regulatory climate which encourages development and in which regulators cooperate with each other. The Sable regulators should shortly conclude agreements providing for cooperation in environmental and regulatory matters. The CNOPB and Province of Newfoundland are cooperating on tricky inter-jurisdictional issues in western Newfoundland.

With the strides which have been made — and are being made - there is cause for optimism. 